\title{
Program Budgeting for Police Departments
}

In Hartford, Connecticut, the residents of a large area in the center of the Negro ghetto are victims of over one-third of the daylight residential burglaries in the city. ${ }^{1}$ Yet during the daytime only one of Hartford's eighteen patrol cars and none of its eleven foot patrolmen is assigned to this area. ${ }^{2}$ Sections in the white part of town about the same size as the central ghetto area receive slightly more intensive daytime patrol even though the citizens in the ghetto area summon the police about six times as often because of criminal acts. ${ }^{3}$ Maps showing the daytime distribution of the automobile patrol in Hartford reveal that in the downtown shopping district and the zone around the State Capitol-an area which is in total about the same size as this central ghetto district-there are approximately four times as many patrol cars and eight times as many foot patrolmen as in the ghetto center.4

One would think that Hartford's decision to protect whites more than Negroes would come under public scrutiny at least once a year, when the City Council' ${ }^{5}$ considers the police budget. But the traditional police budgeting process is poorly designed to reveal any policy decisions. As a result, not only racial discrimination in police protection, but the relative effort expended against various types of crimes is likely to be hidden from public officials examining the budget and even from the police themselves. The traditional line-item budget does not even give Council members the chance to channel funds to specific police activities, such as foot patrol or residential burglary investigations.

1. According to an inspection of an operations map in the police conference room, Police Headquarters, Hartford, Connecticut, November, 1966.

2. The area is bounded by: Main Street on the south; the city limits on the east; Garden, Westland and Vine streets on the north; Albany, Garden and Mather strects on the west. A second patrol car has recently been given as part of its responsibility a small portion of this area. Police Departulent, Gity of HartFord, Manpower Sukvey REPORT 33 (1963) and interviews with Hartford Police Department officials, November 1966.

3. Lists of calls for police service submitted by police officials at November, 1966 , budget hearings. The data are from the period January 1, 1966, through July 15, 1966.

4. Police Department, Ciry of HartFord, supra note 2. During the evenings this imbalance is somewhat redressed. An evening foot patrol has recently been placed in the heart of the ghetto area, for example. It is not suggested that any precisc measurc can be obtained for one "proper" method of allocating Hartford's police manpower from the above figures. The figures do suggest, however, that Hartford's lower-class Negro connmunity receives a disproportionately small share of the protection provided by the police. See note 18 infra.

5. Formally, the Court of Common Council. Hartford, Conn., Rev. Cinarter ch, 3, $\$ 1(1960)$. 
Rather they must choose among such amalgams as wages, office supplies and capital investment. ${ }^{\circ}$

Hartford's budget process displays the shortcomings of traditional budgetary review. The annual cycle begins in November, when the Director of the Budget holds closed hearings in which he, the Chief of Police, and the captains in charge of the various divisions of the police (patrol, traffic, detectives, vice, records) discuss the department's needs for the coming year. In these hearings last year each division captain gave a brief speech describing the pressures on his division and stating that even barely adequate service in the coming year would require more men. ${ }^{7}$ The budget officer had special knowledge of police operations, which enabled him to ask intelligent questions about police policy and efficiency. But the police officials parried questions about policy with assertions that their present practices were clearly "the most efficient." The police rarely offered factual support for these claims, but on most questions the budget official had no facts with which to refute them. Thus questions of policy remained typically shrouded by the myth that the only police policy was "full enforcement" of the criminal law. ${ }^{8}$ In one illustrative exchange during the November, 1966, hearings at Hartford a budget official managed to put together information from two lists and a map on the wall and formulated the question: "Why are your beats of equal size when there are fourteen times as many complaints about crime coming from one as from the other?" He was told that the present force distribution was the most effective one possible, and the issue was dropped.

From the police officer's point of view, the function of these hearings is to convey not information but an impression-an impression of a dedicated and overworked department, beset by adversity, and desperately in need of men and money. The budget official has no way to

6. Hartford's budget is not unique in this regard. See Appendix, p. 833 infra.

7. This response is so typical among police officials that one director of Police Training has sarcastically reduced the entire police budgetary process to a formula: OSQ + CI = MPP: Operational Status Quo + Crime Increase = Nore Police Personncl. Klim. kowski, The Police Budget: The Mistake of Using the OSQ $+\mathrm{CI}=\mathrm{IPP}$ Formula, in THE POLICE Yearbook 50 (1966).

This obsession with manpower increases has helped to produce a serious problem in the police labor market. Many departments are now operating beneath their authorized strength, because city councils have reacted to manpower appeals by raising the authorized strength of the force without increasing salaries to attract enough recruits to fill the newly authorized positions. Educational and intelligence standards for police recruits have been lowered in many cities, a situation acknowledged in the recent report of the President's crime commission. See THE President's Comiassion on Law Evfoncesiest and Administration of Justice, The Chaldence of Crime in a Free Societr 107 (1967).

8. See Goldstein, Police Discretion: The Ideal Versus the Real, 23 Pub. Adms. REv. 140 (1963). 
evaluate this impression or to measure the various requests against one another, much less against the requests of other city departments. $\mathrm{He}$ must rely for the most part upon his opinion of the chief's and the captains' abilities.

In early December the City Manager holds public budget hearings. Each city department is allotted about two hours to make its requests for the coming year. The press is invited, but in the City Manager's public hearing on the police department budget at Hartford in 1966 the only persons present were public officials. There was no effective questioning or discussion of law enforcement policies. For example, the police did not even bring them a map indicating deployment of forces, so there was no way to discuss whether increases or merely adjustments in manpower were needed. Much of the time was spent discussing the purchase of a new switchboard for the police station.

During the next two months the Hartford City Manager prepares the entire city budget. He submits it to the City Council in January, in time for two private Council hearings and one public hearing before approval in late February. At the public budget hearing held by the City Council, schools and taxes are virtually the only topics of discussion. The only public record in the last five years of any discussion about the police department shows a complaint by one citizen that police and firemen were paid too much. ${ }^{9}$

Approximately twenty-five hours are spent each year in public and private hearings on the police budget. At no time are the police called upon to show, with any rigor, how they determine public "needs" for police service and decide which demands for their services are to receive priority.

The form of the traditional budget document is one important reason why time spent scrutinizing the police budget does not contribute to review and control of police policy. The traditional accounting-style budget is designed to keep track, in minute detail, of the expenditure of public funds. It is organized into such categories as "personnel" (wages and salaries, overtime), "non-personal expense" (gasoline, office supplies), and "outlay" (communications equipment, furniture). It is an excellent device for assuring that public funds are not lost or stolen, but tells almost nothing about what is done with them. It does not show how police resources are being allocated, either by neighborhood or by function. A citizen or councilman who wants

9. Hartford Courant, Feb. 1, 1966, at 15, col. 2. 
to know what types of activities the police are emphasizing needs a great deal of unpublished data, such as maps of the car patrol districts and the foot beats, lists of calls for service by neighborhood, and records of case investigations. Even then, he must laboriously piece together the information and attempt to coax inferences from fragmentary data. An efficiency-minded councilman might wish to invest in crime prevention only up to the point at which the city pays no more for additional crime prevention than it saves in losses prevented, ${ }^{10}$ but no such calculation is possible unless the many functions of the police are separated, and a cost attributed to each of them. With the present budgetary system, city officials and the public must wait for fairness and efficiency to emerge spontaneously from within the police department.

Since the City Council has no way of identifying wasteful or undesirable police practices, its members economize in the only way the budget permits: by not appropriating enough funds to put radios in patrol cars, for example, or by refusing each year to replace the police department's ancient typewriters. ${ }^{11}$

But it is difficult to control law enforcement policy with empty storerooms and triplicate requisitions. The device of a program budget allows the public to observe and modify police practices. $A$ program budget shows how much an organization is spending on each of its various jobs. It does not attempt to show in detail what an organization buys-the exact sums spent for manpower, gasoline, or office supplies. Rather it attempts to show what an organization does-in the case of the police, how much money is to be spent for investigation, patrol, and arrest. One possible format for a police program budget is shown below in outline form.12

A budget following this kind of format would show the emphasis which the police give to each major task, such as crime suppression and crime investigation. If the police were also required to furnish such information for particular regions of a city, imbalance in their services would be visible.

The use of program documents is well within the ability of most police departments, especially those in large cities. First of all, police work in different cities is similar enough to allow use of a model

10. Cf. Calabresi, The Decision for Accidents: An Approach to Nonfaull Allocation of Costs, 78 HARv. L. REv. 713 (1965).

11. Police officials cited these instances of past economizing during the November, 1966, closed budget hearings for the police department at Hartford, Connecticut.

12. For a more complete model program budget see Appendix, p. 834 infra. 


\begin{tabular}{|c|c|c|c|c|c|c|}
\hline & & Number & Cost & $\begin{array}{l}\text { Cost/ } \\
\text { Unit }\end{array}$ & $\begin{array}{c}\% \text { of } \\
\text { Category }\end{array}$ & $\begin{array}{l}\% \text { of } \\
\text { Total }\end{array}$ \\
\hline & $\begin{array}{l}\text { Crime Suppression } \\
\text { 1. General patrol } \\
\text { District } 1 \\
\text { District } 2 \\
\text { District } 3 \\
\text { 2. Inspections } \\
\text { 3. Other (Roadblocks, etc.) }\end{array}$ & & & & & \\
\hline 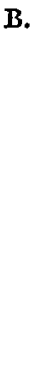 & $\begin{array}{l}\text { Crime Investigation } \\
\text { 1. Answering calls for service: criminal } \\
\text { a. Crimes involving physical danger } \\
\text { to victim } \\
\text { b. Property crimes not involving } \\
\text { physical danger to victims } \\
\text { c. Moral offenses } \\
\text { 2. Investigating crimes } \\
\text { a. Crimes involving physical danger } \\
\text { to victim } \\
\text { b. Property crimes not involving } \\
\text { c. Mysical danger to victim }\end{array}$ & & & & & \\
\hline C. & $\begin{array}{l}\text { Arrest and Prosecution } \\
\text { 1. Arresting suspected offenders } \\
\text { a. Crimes involving .... } \\
\text { b. Property crimes .... } \\
\text { c. Moral offenses } \\
\text { 2. Assisting prosecution }\end{array}$ & & & & & \\
\hline D. & $\begin{array}{l}\text { Non-Criminal Services } \\
\text { 1. Traffic control } \\
\text { 2. Other }\end{array}$ & & & & & \\
\hline E. & $\begin{array}{l}\text { General Support } \\
\text { 1. Administrative } \\
\text { 2. Training } \\
\text { 3. Records } \\
\text { 4. - . . . }\end{array}$ & & & & & \\
\hline F. & Research and Development & & & & & \\
\hline
\end{tabular}

program budget. Each city government can make such minor modifications as it wishes in the model budget, but it will not have to create its own budget format. The program budget in the Appendix to this note is intended to provide a starting point for the development of a model budget. Second, data gathering and processing should not prove unduly burdensome. Detailed information on how officers spend their time can be gathered with little difficulty in brief sample periods during the year..$^{13}$ Although computers may be required for some stages of the data processing, time-sharing schemes and the introduction of microcircuitry should radically decrease computer costs in the near future. ${ }^{14}$ Furthermore, a Presidential proposal now being con-

13. Such data were collected by several municipal police departments for the President's Commission on Law Enforcement and the Administration of Justice. Letter from Samuel G. Chapman, Assistant Director, to R. James Woolsey, Oct. 24, 1966.

14. Interview with Daniel Ross, Stanford Linear Accelerator Computing Center, Stanford, California, in Los Angeles, December 25, 1966. 
sidered by Congress would provide federal financing for sixty to ninety per cent of police planning expenditures. ${ }^{16}$

A program budget will require police officials to make explicit their objectives and priorities. City Councils would then have to take public responsibility for approving or restricting specific police policies. At present, the police often disguise their policy choices for tactical reasons, hiding their exercises of discretion behind the myth of "full enforcement" of the criminal law. They may fear that by acknowledging their policy decisions they will leave themselves open to public criticism, or that courts will reverse convictions on the ground of discriminatory enforcement. ${ }^{10}$

But not all the ambiguity in police objectives is calculated. Traditional management procedures can leave even the police unsure as to why a certain pattern of enforcement has developed. One good example is the common police practice of arresting persons for gambling only when they are in a group whose members don't know one another. It is assumed that this is a sure sign that the gambling is "organized." This policy treats social gambling by the poor more harshly than social gambling by members of the middle class, because in low-income neighborhoods purely social gambling for small stakes, usually with dice, is quite common among unacquainted people. But the practice is not ordinarily a product of conscious discrimination; rather it has simply calcified because no one has thought to question the assump. tion.

Of course a program budget will not instantly expose all police activities to public view. It will not reveal whether police officers are habitually rude, but it could reveal, for example, whether the department makes it a practice to establish roadblocks on holidays to check for drinking. If, for example, a 200 man department uses ten men around the clock on six days a year to establish such roadblocks, this would require about one-half of one per cent of the total available man-hours for that year. This figure is large enough to be made a sub-category of a program budget. Some patterns of discriminatory

15. New York Times, Feb. 12, 1967, \& 4 at E7, col. 1.

The reader may ask, with some justification, why such complex procedures are needed if the data on Hartford in this note could be gathered without the benefit of a program budget. First, the data here are insufficient for any kind of detailed planning. Second, city officials and City Council members might have objections to using the same methods by which data was gathered for this note. For example, at one point the author found himself counting several hundred pins in a pin-map on the wall of the Furtford Police Department conference room.

16. - See Comment, The Right to Nondiscriminatory Enforcement of State Penal Lau', 61 ColuM. L. REV. 1103 (1961) and cases cited therein; see also Goldstein, supra note 8. 
service would also be spotlighted. If the police customarily send only a patrolman to do a cursory investigation of burglaries in the ghetto, but send a squad of detectives to investigate burglaries of wealthy homes, this policy would be revealed by the program budget, because the cost per investigation in the ghetto would be far below the cost per investigation elsewhere. ${ }^{17}$

Some police policies, such as the decision to use "aggressive patrol" in a particular area, may be controlled through the budgetary process even though the program budget will not itself reveal such policies. ${ }^{18}$

17. The 1966 budget hearings in Hartford revealed the discriminatory assignment of patrol forces reported at the beginning of this note. They also showed community dutics which take patrolmen away from their beats. These extra jobs include such tasks as assuring that out-of-town shoppers at Christmas are directed to unfilled parking lots, providing a taxi service to garages for persons whose cars have been towed for illegal parking, and furnishing special traffic direction for employees leaving insurance companles in the afternoon and for children going to and from catechism classes. These services seem to benefit almost exclusively the white middle- and upper-class community. The only service which the police appear to provide for the residents of the ghetto is taking pregnant women to the hospital when ambulance companies refuse to come for fear of not being paid. This job appears to take only about 280 man-hours per year, less than one-tenth as much time as the three other services listed above, but the police contended that this ambulance work was a major reason for inadequate patrol of the Negro ghetto.

Both the general distribution of the patrol force and the special jobs accepted by the police in Hartford indicate that the police have a special sensitivity to the necds of the white middle-class citizens. One reason may be that such persons grow used to having thcir demands for service satisfied by the police and consequently are encouraged to request such service whenever they perceive even the slightest need for it. For cxample, people in Hartford who own large homes are encouraged to request the police to check their houses while they are away on vacation, even though private agencies offer this service. The Police Department has placed a special car on duty during the summer months to provide this service at no charge. At the same time, the residents of two public lousing projects in Hartford have been granted special patrolmen only if the projects will pay them. The police seem to feel that white middle-class citizens have more right to policc services. Once, when the police officials in Hartford were asked why they had first taken a foot patrolman out of the downtown area and then quickly replaced him, they replicel that a fur store had been burglarized in the area soon after the patrolman was removed, and that "after all, these people are the big tax-payers."

This general bias in the Hartford Police Department's service is not idiosyncratic. The most respected municipal police executive in the country, Chicago's Superintendent of Police O. W. Wilson, emphasizes that the police need to enlist the support of businessmen's organizations and "influential men" through special tours, rides in patrol cars, ctc. O. Wilson, POLICE ADMinistration 412-13 (1950). He also notes that the favor of merchants may be useful if it is necessary to bring pressure on newspapers which are unfriendly to the police, because merchants have the power to withhold advertising. Id. at 416 . This sort of bias is manifested in different ways from city to city. In Los Angeles, another city with high standards for the police force, some private groups, such as the California Taxpayers' Association, are admitted to the private hearings of the City Administrative Officer. In these hearings many of the effective decisions about the police budget arc made. Community action groups and civil rights organizations, however, are not admitted. Interview with John Coombs of the City Administrative Officer's staff, Los Angeles, Dec. 22,1966 . In police departments which are less scrupulously managed than those of Chicago and Los Angeles it is not surprising that police officials see infinite opportunity to use their manpower to curry favor with those who can most easily help them or harm thein. In the absence of public review of police policy-making it would be quixotic to cxpect the police to behave differently.

18. It may be contended that policies such as these, which are not directly reflected in program budget categories, should be dealt with outside the budgetary process. If other procedures seem to be necessary they can of course be instituted, but in many 
Public hearings on a program budget, focusing on such topics as " 15 more man-years of patrol for the North Side" rather than " $\$ 100,000$ more for the police department," will be an effective forum for complaints about the police.

So far we have been discussing the contribution which program budgeting can make toward discovering and guiding police policy. Once policy decisions have been made, however, program budgeting can help police officials use their limited resources efficiently so that objectives are met at the least possible expense. A formal technique, known as "cost-effectiveness planning" or "systems analysis," has been developed to guide efficient resource allocation. This technique was first designed to help decision-makers discover the costs and benefits of performing a specific government function by each of several possible methods. For some government jobs, such as providing irrigation, it is possible to find a common denominator, such as dollars, for both the cost of a method and the benefits it will produce. For other jobs, such as crime control, it is difficult to find any commonly-accepted quantitative measure of benefits. This does not mean that the technique is useless for improving efficiency in these tasks. It merely means that the analysis must compare the cost of each method with the effectiveness of that method in accomplishing a specific goal, such as preventing a certain number of crimes against the person. Program budgeting is the first requirement for efficient allocation by such methods. An analogy from the Defense Department may help illustrate this point.

Assume the policy decision has been made to increase the strategic missile force of the United States. Congress and the Defense Department must then decide whether to buy more Polaris missiles, to be launched from submarines, or more Minuteman missiles, to be launched from silos within the United States. It would be difficult to obtain any help toward solving this problem from the information

communities public budget hearings are the traditional forum for complaints about all sorts of public services. See WV. SAYRE aNd H. Kaufaran, Governing NeW Yonk CrTy G1647 (1960). Also, at public hearings just before their budgets are approved, officials may be more receptive to public criticism than in most other circumstances. If such public discussion is ineffective, certain further steps may be necessary. For cxample, it may be that community pressure on City Council members cannot be effective without a public record of Council members' votes on specific appropriations.

The presentation of a community group's position on the police budget would be a useful function for a lawyer in a neighborhood legal office. The context is not a legal one in the narrow sense, but a lawyer's skill in presenting complaints and locating sources of appeal as well as his sense of bureaucratic structure and administrative process could be of great help. Cahn \& Cahn, The IVar on Pozerty: A Civilian Perspectivc, 73 Yals L.J. 1317 (I964). 
supplied by a traditional line-item budget. One could not begin to learn how much it would cost to be able to fire more of either sort of missile. Even if everyone knew that the Polaris was twice as effective as the Minuteman, the choice would not be clear, since each new Polaris might cost five times as much to produce and deploy. A program budget, on the other hand, would bring together in a rough way all the costs associated with the production and deployment of ench type of missile. It would then be comparatively easy to analyze each missile system, compare the cost and effectiveness of each, and come to a decision. The Secretary of Defense need not then be distracted by the irrelevant question of whether the Navy or the Air Force is more "entitled" to the funds.

Mutatis mutandis, police administrators face similar problems. They must decide, for example, whether to patrol an area with oneman cars, two-man cars, motorcycles, or foot patrolmen. Most patrolling work is done by the officers in the patrol division, but some is done by detectives, juvenile squad members, and traffic officers. All of these officers, however, perform many other functions as well. A budget which indicates only how much patrolmen and detectives cost the city gives no useful information about the overall cost of the job of patrolling, much less the cost of each method of patrol. A police administrator must know how much effort, in man-hours and dollars, is being expended for each method of patrol before he will even find it useful to ask questions about the relative effectiveness of each method.

Police officials are generally skeptical of attempts to analyze police effectiveness. ${ }^{19}$ This is doubtless due in part to the same sort of insularity which reigned before McNamara came to the Pentagon. But in part the police have had good cause to be skeptical. Many purported tests of police effectiveness have been exercises in public relations.

19. Some police officials have attempted to work out manpower allocation schemcs without analyzing effectiveness. One of the earliest attempts was by $O$. W. Wilson. Sect Wilson, Distribution of Police Patrol Force, Public Administration Service (No. 74, 1941). Recently many departments in large cities have begun to use variations of this type of manpower allocation scheme. See Walton, "Selective Distribution" of Police Patrol Force (pts. 1-2), 49 J. Crim. L.C. \& P.S. 165,379 (1958). Such schemes doubtless climinate some of the most flagrant misallocations of police manpower, but they are not based on any systematic measures of the cost of crime and the effectiveness of different methods of combating it. For example, in one scheme described by Walton, homicide and hub. cap theft (if the set is worth over $\$ 50$ ) are given the same weight in determining manpower allocation, merely because the FBI labels both of these "Part I Crimes" and uses them to compile its annual "Index of Crime" for the U.S. See id. at 169. In the samc sclicmc, radio calls are given 75 per cent as much weight as "Part I Crimes" "because thcy" represent a clear-cut and tangible demand for police service which can be readlly determined." Id. 
The best-known experiment in police methods was New York City's "Operation 25" in 1954. Twice the usual force of policemen was installed in New York's Twenty-Fifth Precinct for a four month period. All police activities were increased dramatically: patrol forces (foot and auto), detectives, traffic details, juvenile squads, and administrative staff were all bolstered. By comparing 1954 statistics with those for the same period in 1953 , the police found a sharp reduction of reported felonies. ${ }^{20}$

The experiment had two serious shortcomings. No one analyzed crime rates in adjacent precincts, nor did anyone examine the possibility that a change of any kind in police practices might alter the apparent crime rate. ${ }^{21}$ Also the study made no attempt to pinpoint the effect of any one activity. The Police Commissioner of New York City stated that one of the experiment's main purposes was to make a case for a dramatic increase in police manpower. 2

Recently, work has been begun on more sophisticated experiments which seek to pinpoint the effect of specific police practices. Currently the Computer Center of the St. Louis Police Department is attempting to test the effectiveness of uninterrupted police patrol. Patrol cars in the test zone answer no calls for service; these are handled instead by centrally-based cars. Cars in the control zone answer calls in the usual manner. Careful records are kept in the test zone, the control zone, and the area surrounding the test zone to determine whether criminal activity is being suppressed or simply displaced. In addition, crimes are recorded as "suppressible" or "non-suppressible" depending upon their type and location..$^{23}$

Experiments less rigorous than that in St. Louis may yield ambiguous results. If a city merely tries to change some police practice to measure the effect on the crime rate, it will usually find that the effect of the police action is washed out by political and economic changes.

20. Felonious assaults declined $29 \%$, robberies $70 \%$, burglaries $65 \%$, grand larcenies 70\%. Police Department, City of New York, Operation 25, at 10-13 (1955).

21. Such an effect, widely known in social science experiments, is called the "Hawthome effect." It was first noted in an efficiency study of the Western Electric plant at Hawthome, I1l. in 1927. The study showed a marked positive effect on workers' productivity merely because they knew they were participating in an experiment. This effect was much greater than the impact of positive or negative changes in working conditions. Sec F. RoerulusBERGER \& W. Dichson, MANAGeneNt AND THE WORFER (1950). Thus in "Operation 25" a reduction in police manpower might also have produced a fall in the apparent crime rate if a reduced police force had been told that their efforts were being studied.

22. F. Adams, Foreword to Police Department, City of New York, Operation 25, at I (1955).

23. Interview with Scott Hovey, St. Louis Police Department Computer Center, by telephone, July, 1966. 
This problem is another reason for police skepticism about measurement of efficiency. ${ }^{24}$ But well designed experiments, such as that in St. Louis, can correct for all effects except one specific change in police practice, and can thus yield persuasive results. A police administrator would then be able to compare the cost of each patrol method with the effectiveness of that method.

Cost-effectiveness studies, however careful, can give only rough results. A leading writer in the field emphasizes that unless studies show that one method is at least two or three times as efficient as another, the differences are probably small enough that the decision can be made on other grounds without worrying about efficiency.25

In addition, these studies cannot resolve hard questions about values - such as the issue of lives versus property. But they can make it possible to tell a decision-maker something like this: "Patrol of type A can probably prevent about $\$ 1$ million of property loss next year, reduce the number of serious assaults by thirty or forty, and prevent five to ten forcible rapes. Patrol of type $B$ is likely to be only about half as effective as $\mathrm{A}$ in preventing property loss, but will probably be about three times as effective in preventing both rapes and assaults." Thus, it is at least clear what is at stake in choosing one type of patrol rather than another.

Thus although results may be rough and value judgments will still need to be made, studies such as that in St. Louis can be extremely useful. A police department can use program budgeting to see how much it now costs to perform each police function. Then cost-effectiveness studies can determine whether the individual functions are being performed in the most efficient manner.

Program budgeting and systems analysis permit city officials not only to compare the costs of various police operations, but also to determine whether some other city agency could perform a traditional police function at equivalent or lower cost. The scarcity of qualified policemen and the tension which police patrol can produce in some parts of a city should encourage the search for alternate forms of protection.

The police function which might be dealt with most readily by other city departments is crime suppression. "Pure patrol"-mere walking or driving-accounts for 50 per cent of patrol force time and

24. O. Wilson, Police Administration 7 (1950); cf. W. Parker, PArker on Policz 200 (O. Wilson ed. 1957).

25. G. Fisher, The Analytical Bases of Systems Analysis 13-14 (Rand Corporation Paper, May 1966). 
over 30 per cent of most police budgets. The patrolman seeks to suppress crime by creating an "impression of omnipresence." 28 But it might be possible to make potential offenders fear discovery in other ways, such as by improving street lighting. It would be helpful to compare the costs and the effectiveness of lighting to those of pure police patrol time. Although the idea of making such comparisons is not new, program budgeting assures that they will be made systematically, promotes their use, and increases the precision of the data.

Similarly, although police commonly check the doors of commercial establishments at night, Oakland, California, has recently experimented with a compulsory burglar alarm ordinance, a measure which may prove to be both more effective and less costly than door checks by patrolmen. ${ }^{27}$

It is too early to say whether program budgeting for the police will turn out to be more significant because it lays a groundwork for improved efficiency or because it shatters the police's monopoly on policymaking. Either offers a persuasive case for its adoption.

\section{APPENDIX}

A detailed program budget such as the one outlined below will be necessary in order to bring about effective public and City Council control of police policies. Of course, the use of such a budget format does not guarantee such control. In Los Angeles, for example, it was claimed ten years ago that the police used a variety of program budgeting called "performance budgeting." 28 In fact the police department itself does make a detailed breakdown of expenditures within each department, ${ }^{29}$ but this breakdown is never seen by the City Council. The latter sees only the figures for the ten basic categories of police work, such as traffic, juvenile delinquency, and supply.30

In the budget below, the districts which are indicated need not coincide exactly with police patrol districts. The budget districts may be selected for their socio-economic homogeneity in order to determine whether the police are following different policies torvard different social groups. The "cost" categories refer to the cost, in police time, of providing the services listed. They do not refer to the value of property stolen.

26. O. Wilson, Police Administration 81 (1950).

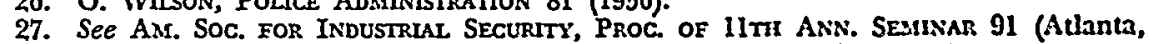
Ga., Oct. 1965) (remarks of Lt. K. Martensen, Oakland, Calif. Police Dept.).

28. W. PARkER, Parker ON Police 90-92 (O. Wilson ed. 1957).

29. The time spent by the patrol force is not, however, broken down into its component parts, as is suggested here.

30. Interview with John Coombs of the City Administrative Offcer's staff, Los Angeles, Dec. 22, 1966. 


\begin{tabular}{|c|c|c|c|c|c|c|}
\hline & & Number & Cost & $\begin{array}{l}\text { Cost/ } \\
\text { Unit }\end{array}$ & $\begin{array}{c}\% \text { of } \\
\text { Category }\end{array}$ & $\begin{array}{l}\% \text { of } \\
\text { Total } \\
\end{array}$ \\
\hline & $\begin{array}{l}\text { Crime Suppression } \\
\text { 1. General Patrol } \\
\text { a. Car } \\
\text { 1. District } 1 \\
\text { 2. District } 2 \\
\text { 3. District 3 } \\
\text { b. Foot } \\
\text { 1. District 1 } \\
\text { 2. District } 2 \\
\text { 3. District 3 } \\
\text { 2. Inspections } \\
\text { a. Commercial } \\
\text { 1. District } 1 \\
\text { 2. District } 2 \\
\text { 3. District 3 } \\
\text { b. Residential } \\
\text { 1. District 1 } \\
\text { 2. District 2 } \\
\text { 3. District 3 } \\
\text { Other (Roadblocks, etc.) }\end{array}$ & & & & & \\
\hline B. & 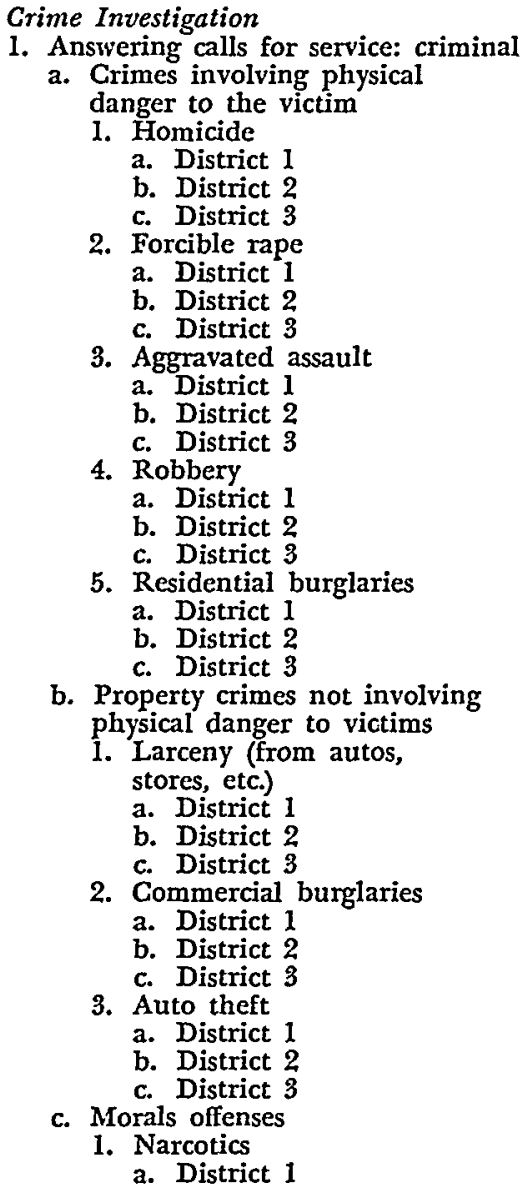 & & & & & \\
\hline
\end{tabular}




\begin{tabular}{|c|c|c|c|c|c|}
\hline & Number & Cost & $\begin{array}{l}\text { Cost/ } \\
\text { Unit }\end{array}$ & $\begin{array}{c}\% \text { of } \\
\text { category }\end{array}$ & $\begin{array}{l}\% \text { of } \\
\text { Total }\end{array}$ \\
\hline 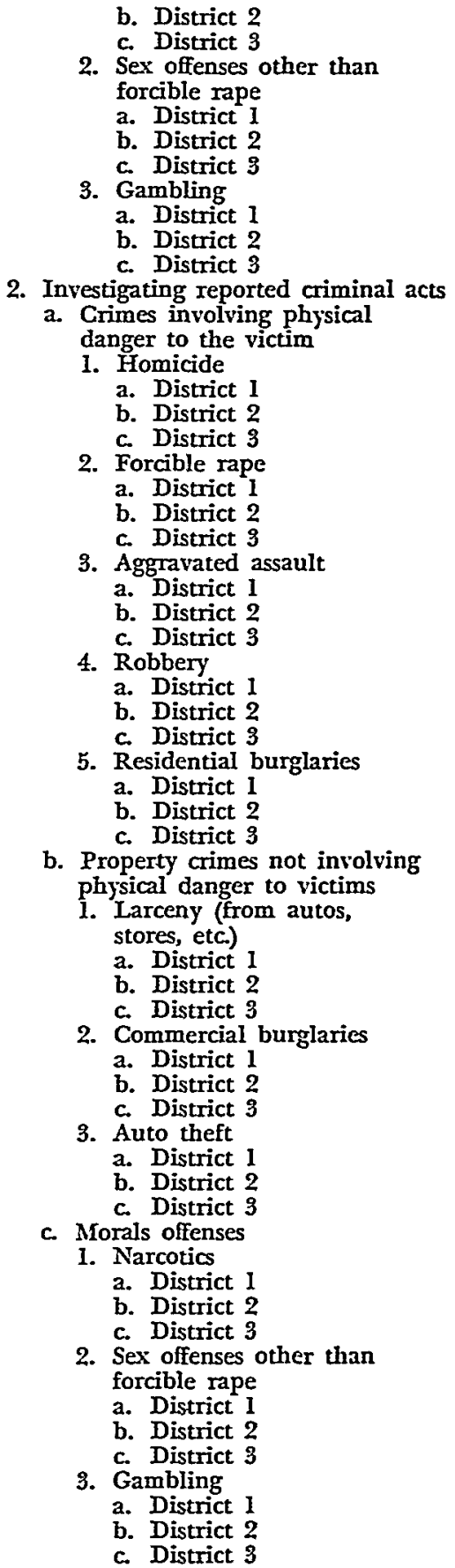 & & & & & \\
\hline
\end{tabular}




\begin{tabular}{|c|c|c|c|c|c|}
\hline & Number & Cost & $\begin{array}{l}\text { Cost/ } \\
\text { Unit }\end{array}$ & $\begin{array}{c}\% \text { of } \\
\text { Category }\end{array}$ & $\begin{array}{l}\% \text { of } \\
\text { Total }\end{array}$ \\
\hline 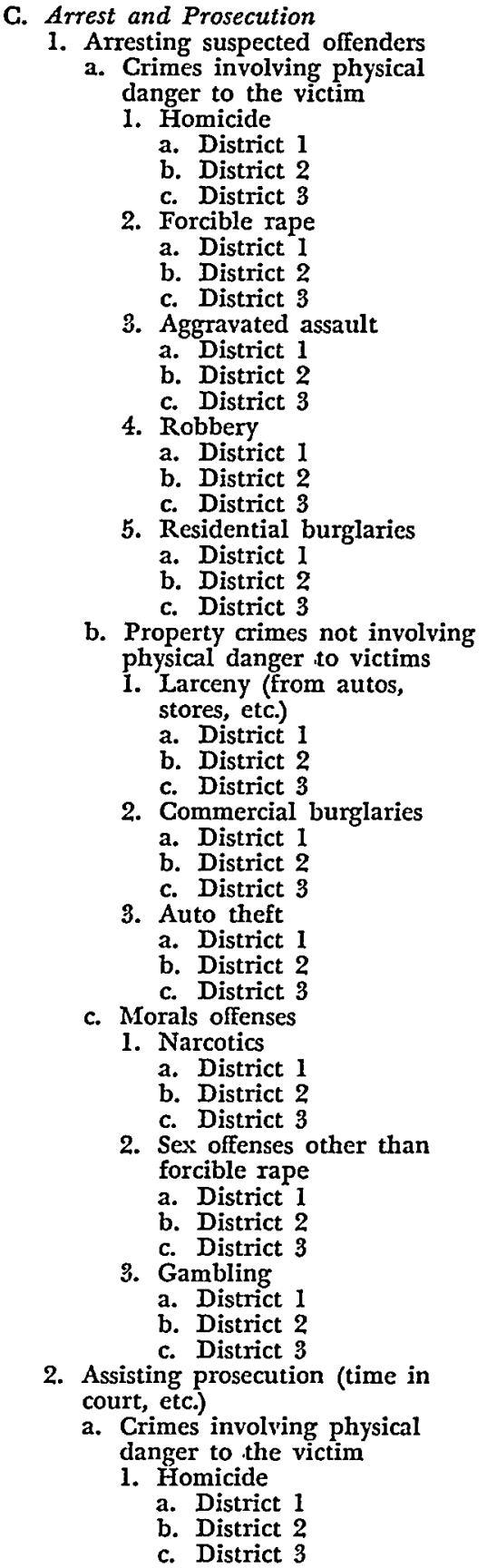 & & & & & \\
\hline
\end{tabular}


Police Budgeting

\begin{tabular}{|c|c|c|c|c|c|}
\hline & Number & Cost & $\begin{array}{l}\text { Cost/ } \\
\text { Unit }\end{array}$ & $\begin{array}{c}\text { \%o of } \\
\text { cilcgory }\end{array}$ & $\begin{array}{l}\text { of of } \\
\text { Total }\end{array}$ \\
\hline 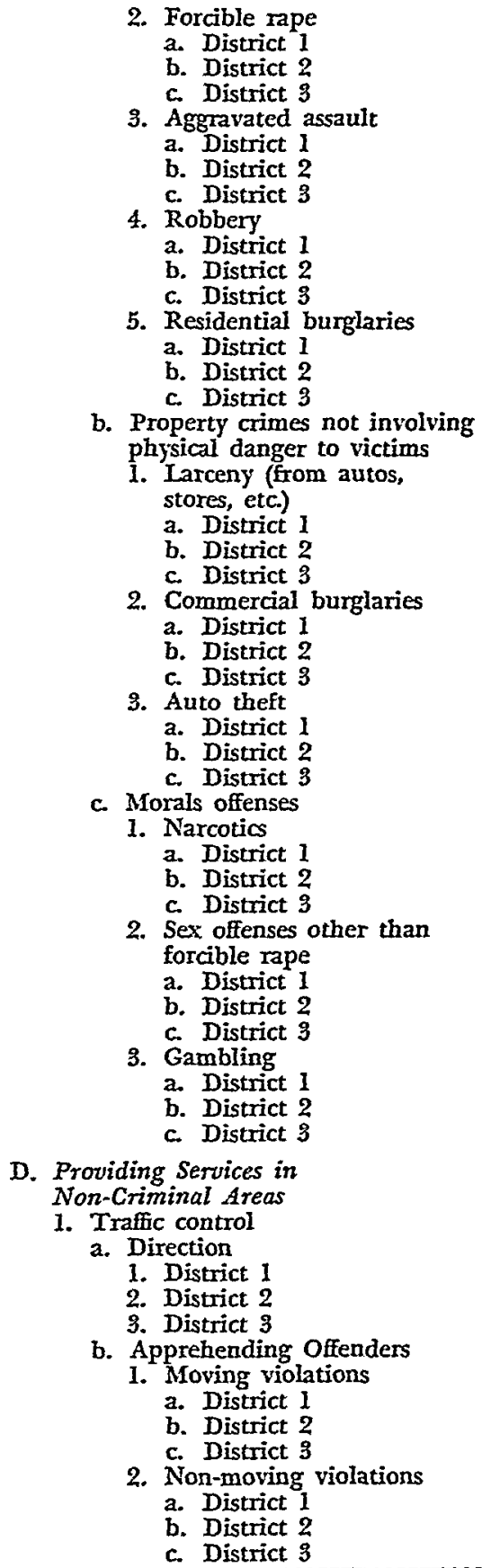 & & & & & \\
\hline
\end{tabular}


The Yale Law Journal

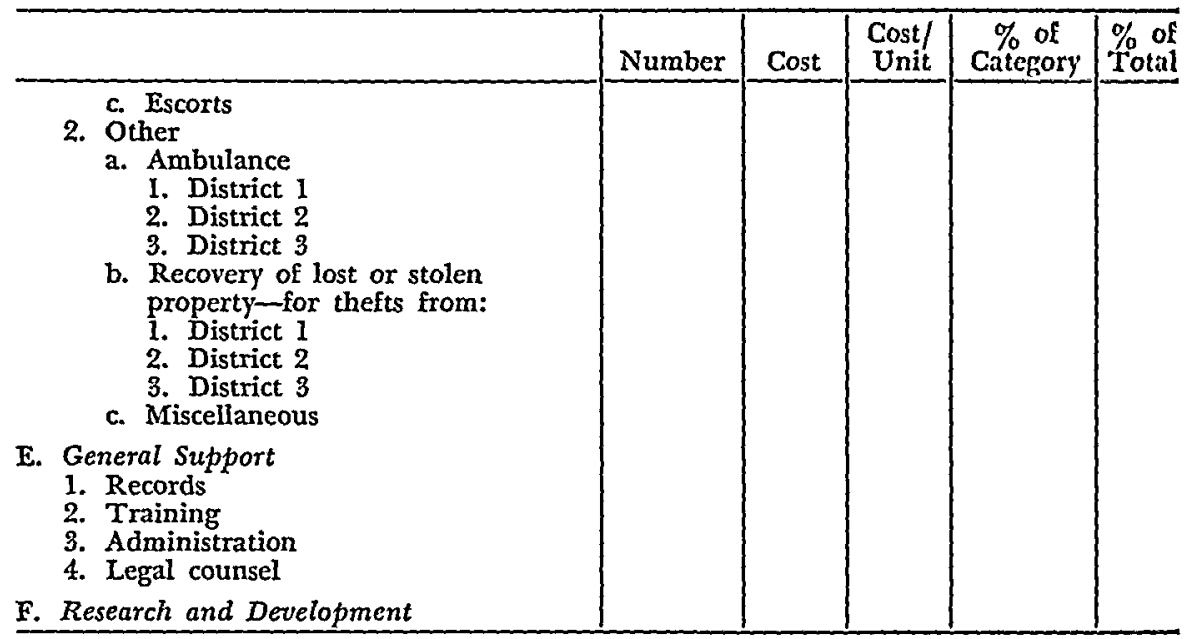

